\title{
Detection of Erysiphe necator in Air Samples Using the Polymerase Chain Reaction and Species-Specific Primers
}

\author{
Jennifer S. Falacy, Gary G. Grove, Walter F. Mahaffee, Heather Galloway, Dean A. Glawe, \\ Richard C. Larsen, and George J. Vandemark
}

First, second, and fourth authors: Washington State University-Irrigated Agriculture Research and Extension Center (IAREC), Prosser, WA 99350; third author: USDA-ARS HCRL, 3420 NW Orchard Avenue, Corvallis, OR 97330 and Oregon State University, Department of Botany and Plant Pathology, Corvallis 97331; fifth author, Washington State University-Puyallup Research and Extension Center, Puyallup 98371; and sixth and seventh authors: Vegetable and Forage Crops Production, USDA-ARS, Prosser, WA 99350. Accepted for publication 23 April 2007.

\begin{abstract}
Falacy, J. S., Grove, G. G., Mahaffee, W. F., Galloway, H., Glawe, D. A., Larsen, R. C., and Vandermark, G. J. 2007. Detection of Erysiphe necator in air samples using the polymerase chain reaction and species-specific primers. Phytopathology 97:1290-1297.

A polymerase chain reaction (PCR) assay employing species-specific primers was developed to differentiate Erysiphe necator from other powdery mildews common in the northwest United States. DNA was extracted from mycelia, conidia, and/or chasmothecia that were collected from grape leaves with a Burkard cyclonic surface sampler. To differentiate E. necator from other erysiphaeceous fungi, primer pairs Uncin144 and Uncin511 were developed to select unique sequences of the internal transcribed spacer regions of E. necator. Using these primers in PCR amplifications, a 367-bp amplicon specific to E. necator was generated, but no amplicons were generated from other erysiphaceous species

coated with silicon grease. During field studies, this PCR assay facilitated the detection of E. necator inoculum in air samples within hours of sample rod collection and prior to disease onset. Amplification of E. necator DNA did not occur when the PCR assay was conducted on vineyard air samples collected while grapes were dormant or during periods when vine growth occurred but E. necator remained dormant. The initial PCR detection of E. necator of the season occurred during seasonal ascospore releases caused by precipitation events between bud burst and the prebloom period during the 3 years of the study. Detection ceased for 7 to 11 days following ascospore release and then resumed several days prior to the observance of microscopic symptoms and signs of powdery mildew in the field. Results of this study represent the initial step toward the goal of incorporating an inoculum availability component into current and future grapevine powdery mildew risk assessment models.
\end{abstract} collected from 48 disparate hosts representing 26 vascular plant families. The PCR limit of detection was one to five conidia of E. necator placed directly into reaction mixtures or 100 to 250 conidia placed on glass rods
Additional keywords: aerobiotia, spore collection.
Powdery mildew caused by Erysiphe necator Schwein. (5) is the most serious disease of grapevines in the arid production region of eastern Washington (10). Losses from the disease have declined in recent years due to the intensive use of sterol demethylation inhibitor and quinone outside inhibitor fungicide products. However, increasing fungicide, fuel, and labor costs make effective disease management costly. Washington growers are seeking ways to lower input costs because of deteriorating grape prices and the desire to reduce pesticide usage.

During the past several growing seasons, symptoms of the disease on fruit rarely were observed and the foliar phase was either absent or developed late in the season (e.g., between the period of bunch closure and veraison or later) (10). Delayed onset of epidemics despite the early-season occurrence of temperature and moisture conditions favorable for ascospore release and primary infection is likely due to the absence, or low levels, of overwintered inoculum in individual vineyards. E. necator perennates in eastern Washington in the form of chasmothecia in bark crevices and attached to abscised leaves on the vineyard floor (10). This primary inoculum source can persist until several weeks after bloom (10). Ascospores constitute primary inocula in vineyards where chasmothecia survive the winter. However, in

Corresponding author: G. G. Grove; E-mail address: grove@wsu.edu

doi:10.1094/PHYTO-97-10-1290

(C) 2007 The American Phytopathological Society vineyards where powdery mildew first appears long after the exhaustion of the ascospore supply in the spring, inoculum (probably conidia) most likely originates from other vineyards and is distributed via wind currents.

Due to the potential for rapid disease development and severe economic loss in the region (10), producers attempt to limit risk by managing their fungicide programs as though inoculum was always present. Fungicide application programs in Washington typically commence between Eichorn-Lorenz stages 09 (two to three leaves unfolded) and 12 (five to six leaves unfolded; inflorescence clearly visible [9]) and continue at 12- to 14-day intervals between applications until veraison. If the pathogen populations are low or if environmental conditions are not conducive for primary infection or subsequent disease development, such season-long chemical suppression may be unnecessary. Under these conditions, it is likely that the current approach to fungicidal control is needlessly expensive and conflicting with goals of fungicide resistance and integrated pest management programs.

Spores of the fungus are dispersed primarily by air currents $(13,35)$ and airborne propagule concentrations of E. necator are largely a function of the population of the fungus in the field. Therefore, a more precise and economical disease management program could result from initiating fungicide programs when initial, low concentrations of E. necator propagules are detected in vineyard air prior to disease onset instead of spraying preventatively based on an arbitrary schedule. Detection of airborne pro- 
pagules for this purpose could be accomplished using airsampling devices in conjunction with an accurate and rapid means of identification.

Conventional identification of erysiphaceous fungi relies on time-consuming microscopic examination of morphological characters (2-5). Other crops and numerous weed species that host erysiphaceous fungi surround many Washington vineyards (G. G. Grove, unpublished data). For example, powdery mildew epidemics commonly occur in apple, cherry, hop, mint, nectarine, or raspberry plantings adjacent to vineyards as well as on weeds growing in the vineyards (G. G. Grove and W. F. Mahaffee, unpublished data). The respective fungi that cause powdery mildew on these crops are taxonomically distinct organisms with morphologically similar anamorphs. Detached conidia of different species tend to resemble each other greatly (2). This diversity of erysiphaceous propagules in the vineyard air compounds the difficulties inherent in identifying species based on the morphological characteristics of conidia and ascospores. Detecting E. necator DNA using the polymerase chain reaction (PCR) could offer a rapid, accurate, and economical means to detect and discriminate $E$. necator in vineyard air samples.

PCR-based diagnostic tools have been developed to identify fungi, bacteria, and viruses for applications in food safety, medical, animal, and crop sciences $(12,16,18,19,23,24,28,32$, $34,36)$ but very little research has focused on molecular-based detection of erysiphaceous species. There is a sizeable body of work characterizing erysiphaceous fungi at the molecular level that could provide a basis for such an effort $(7,8,14,25,30)$. Much of the previous research has focused on the internal transcribed spacer (ITS) region of ribosomal RNA located between the $18 \mathrm{~S}$ and $28 \mathrm{~S}$ subunit genes (33).

The objectives of the present study were to (i) develop a PCR assay that would accurately detect and distinguish E. necator from other erysiphaceous fungi occurring in the Pacific Northwest, and (ii) determine if air sampling devices can be used to collect airborne propagules that will yield DNA suitable for PCRbased detection of E. necator from vineyard air samples.

\section{MATERIALS AND METHODS}

Identification of erysiphaceous fungi and collection of fungal material. Mycelia, conidia, and/or chasmothecia from powdery mildew fungi were collected from infected leaves of wild growing and from cultivated horticultural and agronomic plants representing 48 different plant species within 26 families (Table 1). Each isolate was identified on the basis of host genus and fungal morphology using recent taxonomic concepts of (2-5).

Fungal material (conidia, chasmothecia, and/or mycelia) was collected from host leaves with a Burkard cyclonic surface sampler (Burkhard Mfg. Co., Rickmansworth, UK) and deposited into $1.5-\mathrm{ml}$ microcentrifuge tubes. DNA was extracted immediately from collected material or from samples that were desiccated, flash frozen in liquid nitrogen, and stored at $-70^{\circ} \mathrm{C}$ as described by Stummer et al. (29). Removable parts of the sampler were cleaned between samplings with Formula 409 (2butoxyethanol; Clorox, Pleasanton, CA).

E. necator samples originating from outside Washington State (Table 2) were provided in 70 to $95 \%$ ethanol. Tubes containing preserved leaf material were inverted several times to suspend conidia and other fungal material in the ethanol. Leaf material was removed and the suspension was centrifuged at $1,700 \times g$ for $20 \mathrm{~min}$ in a fixed-angle rotor with a clinical centrifuge (International Equipment Co., Needham Heights, MA). The supernatant was discarded and the DNA was extracted from the fungal pellet as described below.

DNA extraction. DNA was extracted with the FastDNA kit (MP Biomedicals, Irvine, CA) with some modification to the manufacturer's protocol. The supplied fungal extraction buffer
(CLS-Y) was amended with polyvinylpyrrolidone (PVP-40) (Sigma-Aldrich, St. Louis, MO) to a concentration of $2 \%$ (wt/vol). Samples were homogenized for $30 \mathrm{~s}$ at an intensity setting of 5.0 in the FastPrep FP 120 homogenizer (BIO 101/ Savant, Vista, CA). The process was repeated after a 5-min chilling period on ice. After centrifugation for $10 \mathrm{~min}$ at $14,000 \times$ $g, 800 \mu \mathrm{l}$ of the aqueous phase was transferred to a $1.7-\mathrm{ml}$ microcentrifuge tube and extracted with an equal volume of phenolchloroform-isoamyl alcohol (25:24:1, vol/vol). The supernatant $(600 \mu \mathrm{l})$ was transferred to a clean 1.7-ml tube and the DNA bound to a matrix using the supplied binding buffer, washed, and then eluted with $100 \mu \mathrm{l}$ of sterile distilled water. DNA extracts were stored at $-20^{\circ} \mathrm{C}$ and diluted 1:6 with DNAse- and RNAsefree deionized water prior to amplification. All DNA preparations were amplified using universal primers ITS1 and ITS4 as described by White et al. (33). These amplifications served as a positive control indicating successful fungal DNA extraction. The concentration of $E$. necator DNA was determined with a TD-700 flourometer (Turner Designs, Sunnyvale, CA) and diluted to $33.3 \mathrm{pg} / \mathrm{ml}$ in DNAse and RNAse-free water. This control was then diluted 1:6 with DNAse and RNAse-free water and used as DNA template in subsequent PCR assays.

Primer design. Forty-five sequences of erysiphaceous fungi deposited in GenBank by Saenz and Taylor (25) were aligned using Clustal W software (31). Highly conserved regions specific to E. necator were used in the design of forward primer Uncin 144 (CCGCCAGAGACCTCATCCAA) and reverse primer Uncin511 (TGGCTGATCACGAGCGTCAC) using Primer Designer 4 (SciEd, Cary, NC) software. Primers Uncin144 and Uncin511 are nested between (ITS) regions that are bracketed by the universal primers ITS1 and ITS4 (33). The universal ITS primers and primers Uncin144/Uncin511 amplify 565- and 367-bp fragments, respectively, for each primer pair.

PCR assays. PCR assays using $1 \mu$ of purified DNA were conducted in $25-\mu \mathrm{l}$ reaction mixtures containing $20 \mathrm{mM}$ Tris- $\mathrm{HCl}$ (pH 8.8), $10 \mathrm{mM} \mathrm{KCL,} 10 \mathrm{mM}\left(\mathrm{NH}_{4}\right)_{2} \mathrm{SO}_{4}, 2 \mathrm{mM} \mathrm{MgSO}_{4}, 0.1 \%$ Triton X-100, $0.1 \mathrm{mg} / \mathrm{ml}$ bovine serum albumin, $3 \mathrm{mM} \mathrm{MgCl}$, $120 \mu \mathrm{M}$ each of dATP, dTTP, dCTP, dGTP, $2.5 \mu \mathrm{M}$ of each primer, and 0.1 unit of Pyrococcus furiosus (Pfu) DNA polymerase (Stratagene Corp., La Jolla, CA). A TGradient thermocycler (Whatman Biometra GmbH, Göttingen, Germany) was used with an optimized final profile of 2-min initial denaturation at $96^{\circ} \mathrm{C}$, followed by 35 to 40 cycles of $30 \mathrm{~s}$ at $95^{\circ} \mathrm{C}, 30 \mathrm{~s}$ at $65^{\circ} \mathrm{C}$ (with universal primers) or $70^{\circ} \mathrm{C}$ (with E. necator-specific primers), $30 \mathrm{~s}$ at $70^{\circ} \mathrm{C}$ and a single final extension period of $7 \mathrm{~min}$ at $70^{\circ} \mathrm{C}$. Amplified DNA was resolved on a $1 \%$ agarose gel in $0.5 \times$ Tris-borate-EDTA buffer $(90 \mathrm{mM}$ Tris-borate and $2 \mathrm{mM}$ EDTA). Amplified DNA fragments were stained with ethidium bromide and visualized under UV light with an AlphaImager 2000 (Alpha Innotech, San Leandro, CA) after electrophoresis at $110 \mathrm{~V}$ for $2 \mathrm{~h}$. The amplifications were repeated at least twice for each specimen. A test was considered successful for differentiating E. necator from other erysiphaceous fungi only if (i) amplification with universal primers ITS1 and ITS4 yielded a product, and if (ii) amplification with primers Uncin144 and Uncin511 resulted in a 367-bp fragment.

DNA cloning and sequencing. A 367-bp DNA fragment was amplified by PCR using primers Uncin144 and Uncin511. The amplicons were excised from agarose gels and purified with the GeneClean Turbo kit (Bio 101 Inc., Vista, CA). DNA was cloned into the vector pCR4-Topo with the Topo TA cloning kit (Invitrogen, Carlsbad, CA) according to the kit instructions. Plasmid DNA was purified using alkaline lysis (26) and clones containing the PCR product were identified by an additional PCR with the purified plasmid DNA as template using primers Uncin144 and Uncin511. DNA from eight candidate clones was sequenced in both directions using the dideoxy-chain termination method at the Laboratory for Biotechnology and Bioanalysis, 
School of Molecular Biosciences, Washington State University and compared with the available sequence for E. necator (GenBank accession no. AF011325).

Sensitivity studies. For direct amplification from conidia or conidial chains, one conidium or chains comprised of two to five spores were harvested from immature, infected grape leaves using a using an eyelash attached to a glass Pasteur pipette. Under a dissecting microscope, conidia were transferred to a PCR tube containing the PCR master mix. Tubes were centrifuged for $10 \mathrm{~s}$ and then frozen at $-20^{\circ} \mathrm{C}$ before being placed in the thermocycler. Freezing of the master mix containing the spores and lengthening of the initial denaturation step was performed to facilitate conidia disruption. PCR parameters were optimized to include a 6-min initial denaturation at $96^{\circ} \mathrm{C}$ prior to the cycling parameters described previously and the number of PCR cycles was increased to 45 .

Rotorod air samplers (Sampling Technologies Inc., Minnetonka, $\mathrm{MN}$ ) equipped with glass rods $(5 \mathrm{~cm}$ by $1 \mathrm{~mm}$ ) coated with highvacuum silicon vacuum grease (Dow Corning, Midland, MI) were used in all air sampling experiments. This configuration sampled 408 liters of air per minute. In order to determine the sensitivity of the PCR assay when used in conjunction with the air sampling method, DNA was extracted from coated (with silicon grease) glass rods on which 0,1 , and about $50,100,250$, or 500 conidia

TABLE 1. Erysiphaceous fungi that yielded a single 565-bp amplicon from polymerase chain reaction, using primers internal transcribed spacer 1 (ITS1) and ITS4, and failed to produce an amplicon when primers Uncin144 and Uncin511 were used

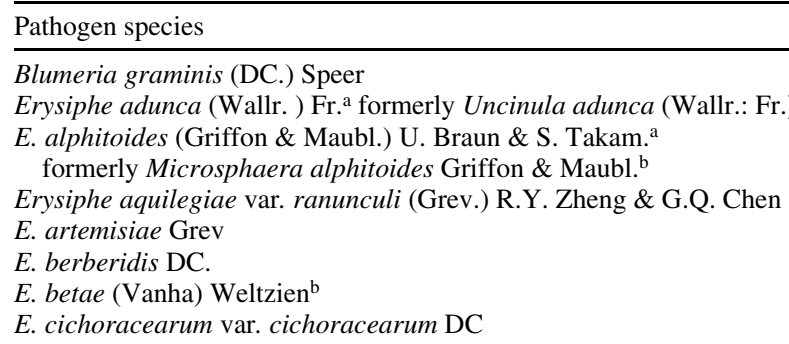

E. convolvuli DC

E. euonymi-japonici (Vienn.-Bourg) U. Braun \& S. Takamatsu ${ }^{\mathrm{a}}$ formerly Microsphaera euonymi-japonici Vienn.-Bourg ${ }^{\mathrm{b}}$

E. flexuosa (Peck) U. Braun \& S. Takamatsua formerly Uncinuliella flexuosa Peck ${ }^{\mathrm{b}}$

E. glycines F. L. Tai

E. liriodendri Schwein

E. magnicellulata var. magnicellulata $\mathrm{U}$. Braun

E. nemopanthis (Peck) U. Braun \& S. Takam.) ${ }^{\mathrm{a}}$ formerly Microsphaera nemopanthi Peck ${ }^{\mathrm{b}}$

E. pisi DC

E. polygoni DC

E. syringae Schwein. syn Microsphaera syringae (Schwein)H. Magn

\section{E. rhododendri J. N. Kapoor}

Golovinomyces cynoglossi (Wallr.) V. P. Heluta

Leveillula taurica (Lév.) G. Arnaud

Neoerysiphe galeopsidis (DC.) U. Braun

Oidium sp.

Podosphaera aphanis (Wallr.) U. Braun \& S. Takam. ${ }^{a}$ formerly Sphaerotheca aphanis (Wallr.) U. Braun ${ }^{\mathrm{b}}$

Podosphaera clandestina (Wallr.) Lév.

P. delphinii (P. Karst) U. Braun \& S. Takam. ${ }^{a}$ formerly S. delphinii (P. Karst) S. Blumer ${ }^{\mathrm{b}}$

P. fusca (Fr.) U. Braun \& N. Shishkoffa formerly Sphaerotheca fusca (Fr.) S. Blumer

P. leucotricha (Ellis \& Everh.) E. S. Salmon

P. macularis (Wallr.) U. Braun \& S. Takam. ${ }^{a}$ formerly Sphaerotheca macularis (Wallr.) Lind ${ }^{\mathrm{b}}$

P. pannosa (Wallr.) de Bary ${ }^{\mathrm{a}}$ formerly Sphaerotheca pannosa (Wallr.) Lév ${ }^{\mathrm{b}}$

P. violae (U. Braun) U. Braun \& S. Takam. ${ }^{a}$ formerly Sphaerotheca violae U. Braun ${ }^{\mathrm{b}}$

Phyllactinia guttata (Wallr.) Lév

Sawadaea bicornis (Wallr.) Homma

a Binomial fide Braun and Takamatsu (5)

b Binomial fide Braun. (2).

\begin{tabular}{|c|c|}
\hline Host genus and species & Origin \\
\hline Poa sp. & Prosser, WA \\
\hline Populus sp. & Fairbanks, AK \\
\hline Quercus robur $\mathrm{L}$. & Seattle, WA \\
\hline Aquilegia canadensis $\mathrm{L}$. & Pullman, WA \\
\hline Tanacetum vulgare $\mathrm{L}$. & Prosser, WA \\
\hline Mahonia aquifolium (Pursh.) Nutt. & Pullman, WA \\
\hline Beta vulgaris L. subsp. cicla (L.) W. Koch & Mt. Vernon, WA \\
\hline Aster sp. & Prosser, WA \\
\hline Coreopsis sp. & Prosser, WA \\
\hline Cosmos sp. & Kennewick, WA \\
\hline Chrysanthemum maximum Cav. & Prosser, WA \\
\hline Taraxacum officinale Wigg. & Pullman, WA \\
\hline Lactuca serriola L. & Prosser, WA \\
\hline Rudbeckia laciniata $\mathrm{L}$. & Prosser, WA \\
\hline Convolvulus arvensis $\mathrm{L}$. & Prosser, WA \\
\hline Euonymus fortunei Hand.-Mazz. & Benton City, WA \\
\hline Aesculus sp. & Moscow, ID \\
\hline Lupinus perennis $\mathrm{L}$. & Pullman, WA \\
\hline Liriodendron tulipifera $\mathrm{L}$. & Bent Creek, NC \\
\hline Phlox paniculata $\mathrm{L}$. & Benton City, WA \\
\hline Ilex verticillata $(\mathrm{L}$.$) A. Gray$ & Benton City, WA \\
\hline Medicago sativa $\mathrm{L}$. & Prosser, WA \\
\hline Pisum sp. & Richland, WA \\
\hline Polygonum convolvulus $\mathrm{L}$. & Prosser, WA \\
\hline Trifolium sp. & Moscow, ID \\
\hline Syringa vulgaris $\mathrm{L}$. & Prosser, WA \\
\hline Ligustrum japonicum Thunb. & Seattle, WA \\
\hline Caragana arborescens Lam. & Moscow, ID \\
\hline Rhododendron sp. & Seattle, WA \\
\hline Amsinckia tessellata Gray & Richland, WA \\
\hline Pulmonaria sp. & Bellingham, WA \\
\hline Allium cepa $\mathrm{L}$. & Pullman, WA \\
\hline Ajuga sp. & Prosser, WA \\
\hline Laburnum anagyroides Medik. & Pack Forest, WA \\
\hline Rubus ursinus Cham. \& Schlechtend. & Pack Forest, WA \\
\hline Prunus avium $\mathrm{L}$. & Prosser, WA \\
\hline Ranunculus abortivus L. & Prosser, WA \\
\hline Monarda didyma $\mathrm{L}$. & Prosser, WA \\
\hline Cucurbita maxima Duchesne & Benton City, WA \\
\hline & Bellingham, WA \\
\hline Malus domestica Borkh. & Prosser, WA \\
\hline Humulus lupulus L. & Prosser, WA \\
\hline Rosa gallica $\mathrm{L}$. & Prosser, WA \\
\hline Prunus persica $\mathrm{L}$. & Prosser, WA \\
\hline Prunus persica nucipersica (Suckow.) C. K. Schneid. & Prosser, WA \\
\hline Viola renifolia A. Gray & Bellingham, WA \\
\hline Corylus cornuta Marsh. & Seattle, WA \\
\hline Acer platanoides $\mathrm{L}$. & Pullman, WA \\
\hline
\end{tabular}

Pullman, WA 
of E. necator had been placed. Each conidium or chain of conidia was picked from young colonies of E. necator using an eyelash fastened to a Pasteur-pipette and placed on a rod. The number of conidia on each rod were confirmed my microscopic observation. Rods were broken into two to three pieces with forceps and placed into FastDNA tubes containing a garnet matrix and a $6.4 \mathrm{~mm}$ ceramic sphere, and the DNA was subsequently extracted as described previsouly. The final extract was diluted 1:10 for PCR amplifications. The experiment was repeated 14 times. For statistical analysis, arcsin $\sqrt{\text { proportion successful amplification }}$ (20) was regressed on the number of conidia placed onto glass rods. The analysis was performed using JMP Statistical Analysis Software (SAS Institute, Cary, NC).

Air sampling. A vineyard comprised of 2 ha of 3- to 6-year-old own-rooted 'Chardonnay' and 'Riesling' vines located at the Irrigated Agriculture Research and Extension Center about $7 \mathrm{~km}$ North of Prosser, WA, was used in 2003 to 2006 field studies. In order to assess the temporal concentration of E. necator propagules in the air during the course of Rotorod/PCR studies, a Burkard volumetric spore trap was placed in the vineyard. The trap was operated continuously over the course of the study and was adjusted to sample approximately 10 liters of air per minute. Trapping tapes were removed at weekly intervals, cut into segments corresponding to 24 -h periods, stained with acid fuchsin, and mounted on glass slides. These were examined at $\times 200$ under a compound microscope. The number of ascospores and conidia exhibiting features of E. necator (2) trapped per hour were recorded and totaled over 24 -h periods in order to determine when ascospore release events occurred and thereby help assess the validity of any positive or negative results from the PCR analysis of Rotorod samples. A CR-21X (Campbell Scientific, Logan, UT) datalogger positioned $10 \mathrm{~m}$ from the trap provided continuous records of temperature, relative humidity, rainfall, leaf wetness, wind speed, wind direction, and solar radiation. The potential for ascospore release was determined using established rules for ascospore release: average daily temperature above $10^{\circ} \mathrm{C}$ with $2.5 \mathrm{~mm}$ of rainfall $(10,21)$.

During the summer of 2003, a Rotorod sampling device was utilized in conjunction with the PCR detection technique to assess the potential for the collection and identification of airborne propagules of E. necator from a vineyard severely infested with E. necator. The air sampler was fastened to the apex of a $1.5-\mathrm{m}-$ high antenna tripod and placed on the leeward edge of the vineyard. The sampler was operated continuously between 10 a.m. and 2 p.m. on 23 July and 2 August. At the time of sampling, powdery mildew incidence and severity was extremely high. Puta- tive E. necator amplification products generated from each sample rod of the two air samples were cloned, sequenced, and compared with the published sequence of the fungus as described above.

More extensive vineyard studies were conducted during 2004 to 2006. The sampling method employed a single stationary Rotorod trap located at the leeward edges of the vineyard mounted on a pipe at canopy height approximately $1.5 \mathrm{~m}$ above the ground. The device was operated continuously and the rods were collected every 2 to 3 days beginning 1 month prior to bud burst (early March) to harvest in 2004 and 3 months prior to bud burst (early January) to shortly after veraison in 2005 and 2006. In all vineyard studies, on every third day beginning at bud burst, 50 leaves on each of 25 vines were selected at random and were evaluated for early symptoms and signs of infection by E. necator.

\section{RESULTS}

Primer design. Alignment of the complete ITS regions of the 45 erysiphaceous fungi sequenced by Saenz and Taylor (25) revealed both highly conserved and heterogeneous regions. Primers Uncin144 and Uncin511 were selected on the basis of sequences unique to E. necator. Sequence analysis using BLAST (1) search showed that primers Uncin144 and Uncin511 shared $100 \%$ sequence identity with the E. necator (AF011325) sequence deposited in GenBank and less than $90 \%$ identity with any other available sequence for Erysiphe spp.

PCR assays. Primers Uncin144 and Uncin511 generated amplification products of the expected 367-bp size from all $E$. necator isolates collected, regardless of geographic origin (Table 2 ). No amplification products were generated with the primers when tested using DNA from 35 other species of the Erysiphales collected from 48 different plant species (Table 1).

Sensitivity studies. DNA of E. necator that had been extracted from five, two, and one conidia was detected in 85,60 , and $46 \%$ of reactions, respectively. Although as few as 10 conidia were occasionally detected on glass rods coated with silicon grease, consistent PCR amplification required between 100 and 500 conidia (Fig. 1). Regression analysis revealed a significant $(F=$ 29.0; $P=0.004)$ relationship $(y=1.6 \times \exp (-\exp (-(x-35.5) /$ $40.5))$ ) between the numbers of conidia placed on glass sampling rods and successful PCR amplifications with a coefficient of determination $\left(r^{2}\right)$ of 0.97 . In sensitivity tests, serial dilutions of DNA extracted from leaves infected with E. necator were used as template for PCR amplification. It was determined that a dilution of 1:10 from the final DNA product resulted in the most consistent detection.

TABLE 2. List of Erysiphe necator isolates from various viticulture regions yielding a single 367-bp amplicon from polymerase chain reaction using primers Uncin144 and Uncin511

\begin{tabular}{lll}
\hline E. necator isolate & Origin & Source \\
\hline 2B17 & France & F. Delmotte \\
BR8 & France & F. Delmotte \\
CC43 & France & F. Delmotte \\
CC12 & France & F. Delmotte \\
Lat13 & France & F. Delmotte \\
Be3 & France & F. Delmotte \\
Turloc 1 & California & D. Gubler/T. Miller \\
Orcutt 1b & California & D. Gubler/T. Miller \\
Sonoma Co 1b & California & D. Gubler/T. Miller \\
Fresno Co. 1e & California & D. Gubler/T. Miller \\
Fresno Co. 1d & California & D. Gubler/T. Miller \\
EWA & E. Washington & G. Grove/J. Falacy \\
WWA & W. Washington & L. du Toit \\
Mad 28 & New York & D. Gadoury \\
Pal II & New York & D. Gadoury \\
Fr 25 & New York & D. Gadoury \\
Fr 40 & New York & D. Gadoury \\
FR 38 & New York & D. Gadoury \\
Mad 17 & New York & D. Gadoury \\
\hline
\end{tabular}


Air sampling. PCR products obtained from air samples collected by Rotorod sampling devices indicated that a sufficient number of spores were trapped and that the extracted DNA was suitable for amplification with primers ITS1 and ITS4 as well as Uncin144 and Uncin511. Sequences of the amplification products were $100 \%$ identical to sequences of the E. necator ITS region.

In the preliminary vineyard study conducted in 2003, E. necator was detected in both air samples taken from the mildewinfested vineyard. Single 367-bp fragments were produced with primers Uncin144 and Uncin511. The two amplified products (one from each sample rod) from each air sample were confirmed as E. necator as described previously. During the two respective days of the experiment, the presence of E. necator in the vineyard air was confirmed by the collection of 684 and 1,228 conidia ( 0.05 and 0.09 conidia per liter, respectively) by the Burkard sampler.

E. necator was not detected in air samples collected during the dormant season during all years of the study. After bud burst on 15 April 2004, the pathogen was detected in samples collected from the vineyard from 7 to 10 May (days of year 128 to 130; Fig. 2) about 3 weeks prior to the first visual observation of signs of the disease on 3 June (day of year 155). Microscopic assessment of the Burkard tapes revealed that the two initial positive PCR detections coincided with ascospore releases that were initiated by $0.35-$ and $0.58-\mathrm{cm}$ rain events occurring on 8 May (day of year 127) and 15 May (day of year 136), respectively. Seventeen and nine ascospores (but no conidia) were trapped by the Burkard sampler during these respective rain events, indicating that the air samples collected from 8 to 11 May (days of year 127 to 130 ) and 14 to 17 May (days of year 135 to 138 ) most likely contained ascospores of E. necator. E. necator was not detected in the vineyard air for 10 days following the latter ascospore release. Aerial propagules of E. necator were again detected 5 days prior to the observance of microscopic foliar powdery mildew signs and 8 days prior to detection of E. necator conidia by the Burkard sampler. The initial PCR detection in 2005 occurred as a result of an extended $1.25-\mathrm{cm}$ rain event from 24 to 26 May (days of year 144 to 146), about 36 days after bud burst. Fourteen ascospores were identified in the Burkard samples during this event. E. necator was not detected in the vineyard air for 9 days following the ascospore release. PCR detection resumed 8 days prior to the observance of microscopic signs of powdery mildew and 7 days prior to detection of E. necator conidia by the Burkard sampler. In 2006, the initial PCR detection occurred during an extended $1.1 \mathrm{~cm}$ rain event on 19 to 23 May (days of year 139 to 143). Six ascospores were identified in the Burkard samples taken during this event. E. necator was not detected in the vineyard air for 11 days following the ascospore release. PCR detection resumed 9 days prior to the observance of microscopic signs of powdery mildew and 5 days prior to detection of E. necator conidia by the Burkard sampler.

\section{DISCUSSION}

Using the Uncin144 and Uncin511 primers and a Rotorod air sampler, it was possible to use a single PCR amplification (within hours of sample rod collection) to detect DNA airborne propagules of E. necator in the vineyard prior to observation of disease symptoms. The initial detection corresponded to predicted ascospore release events resulting from rain or irrigation events with $\geq 2.5 \mathrm{~mm}$ in $24 \mathrm{~h} \mathrm{(21)}$ that were confirmed by the presence of ascospores on impaction tapes from a Burkard volumetric spore trap. Negative sampling results prior and subsequent to the positive detections indicate that the vineyard air contained $<0.0002$ conidia per liter of air and was likely devoid of E. necator propagules during incubation and latent periods and that primers Uncin144 and Uncin511 are specific to E. necator.

Undoubtedly the aerospora of vineyards in Eastern Washington is a mixture of pollen, bacteria, fungal spores, and other particles containing DNA that could be amplified by primers Uncin 144 and Uncin511. However, processing numerous samples of vineyard aerospora did not result in production of an amplicon using Uncin144 and Uncin511 during periods when grape powdery mildew was not predicted to be $(11,17,21)$ or known to be present. Furthermore, Uncin144 and Uncin511 were tested

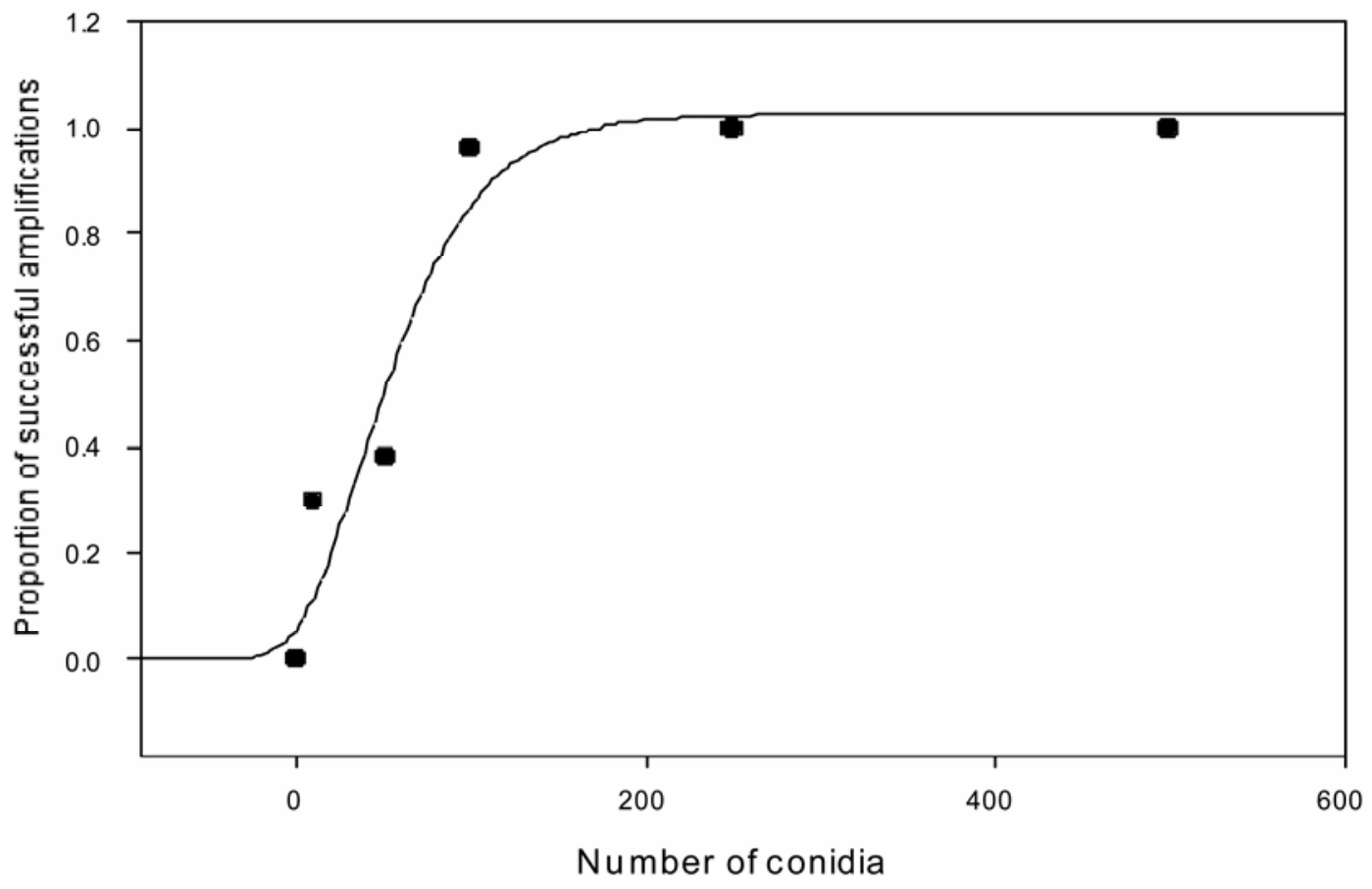

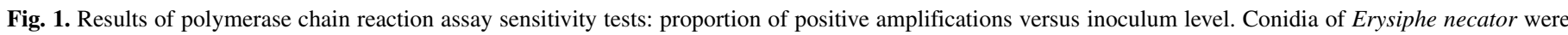

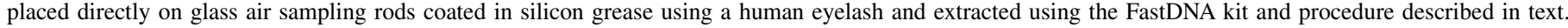

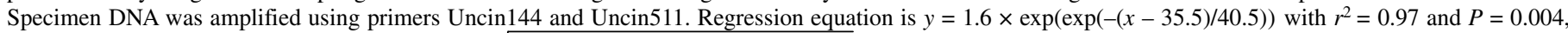
respectively, and was derived by regressing $\arcsin \sqrt{\text { proportion successful amplification }}$ on the number of conidia placed onto silicon coated glass rods. 
extensively for cross-reaction to 35 other erysiphaceous fungi from 48 plant species found in the region. These data support the conclusion that the primers Uncin144 and Uncin511 are specific to E. necator when using the extraction and PCR conditions described. These primers also appear to be suitable for detection of most if not all isolates of E. necator because they successfully amplified numerous $E$. necator isolates from diverse geographic regions.

In addition to being specific, the primers and PCR procedure appear to be sensitive. When conidia were transferred directly to PCR mixtures, one to five conidia could be successfully detected 46 to $85 \%$ of the time, while 100 and $\geq 250$ conidia could be detected $>98$ and $100 \%$ of the time, respectively, when spores were placed on glass rods coated with silicon grease. The sensitivity of this assay is somewhat less than reported by Sholberg et al. (27) where 20 to 30 conidia of Podosphaera leucotricha were detected on apple leaf disks or air sampling rods; however, our technique required only one PCR instead of the two required when conducting nested PCR. The sensitivity of the techniques described herein could perhaps be improved through the use of a water-soluble coating (as opposed to silicon grease) on air sampling rods or through the use of nested PCR. The sensitively has been further increased (10 conidia on sample rods) with a nonphenolic DNA extraction procedure developed by Peetz at al. (22) for the detection of P. macularis from air samples from hop yards (G. G. Grove, unpublished data).

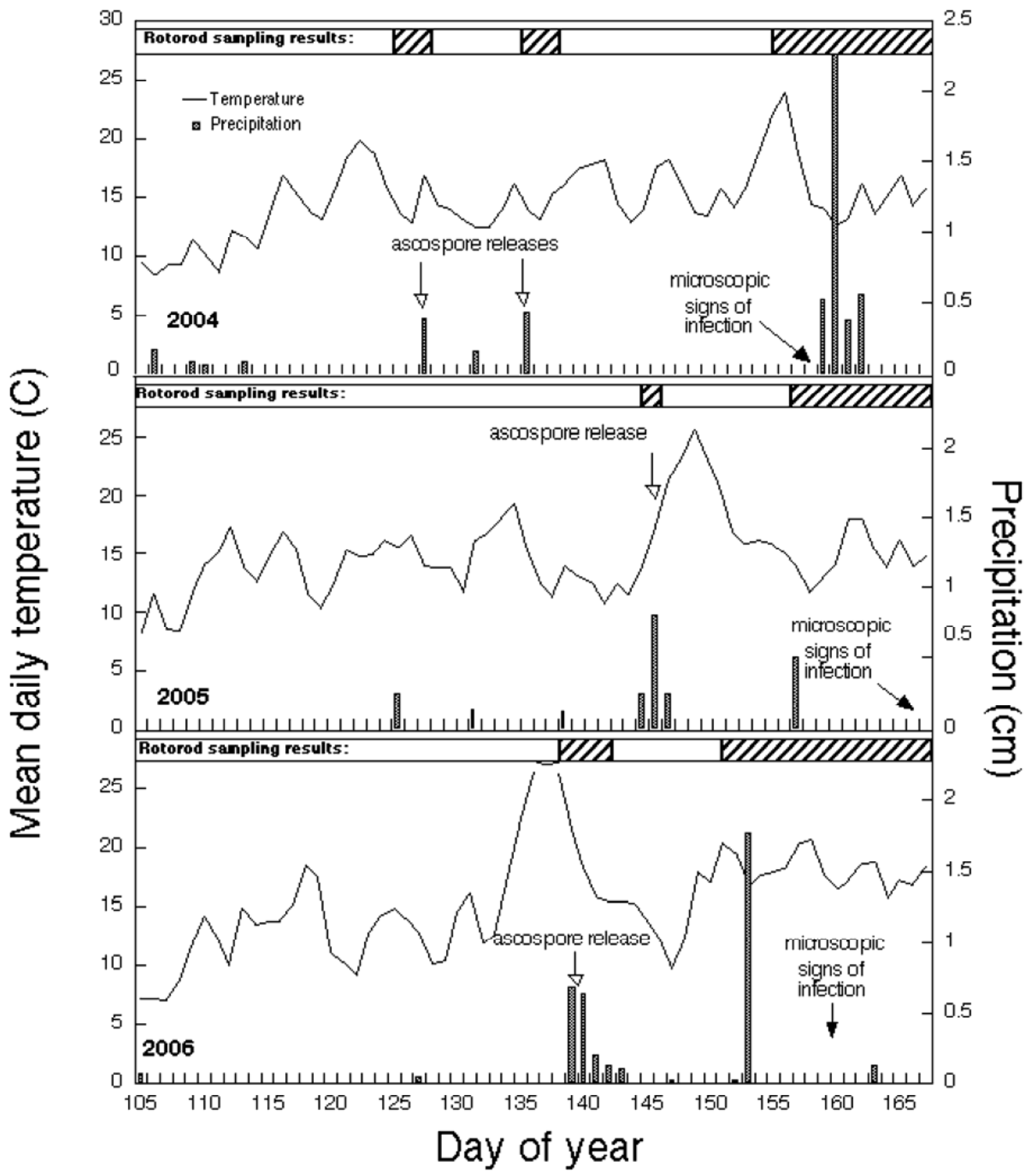

Fig. 2. Results of 2004 through 2006 studies using the polymerase chain reaction (PCR)-based technique for detection of Erysiphe necator in vineyard air samples. The horizontal bar in the upper portion of each graph indicates the time period over which vineyard air was sampled during the growing season. The white segment indicates the period in which no amplification of E. necator DNA occurred. Segments represented by diagonal lines indicate sampling periods where positive PCR amplification indicated the presence of E. necator in the vineyard air. Displayed are daily mean temperature (Celsius; solid line), precipitation (cm; bars), and ascospore releases (open arrows), confirmed with a Burkard air sampler and morphological features for propagule identification, and appearance of powdery mildew signs (visible mycelia) in the vineyard (solid arrows) over the sampling periods. 
Extensive modification of the Fast DNA kit protocol was necessary to ensure successful and consistent amplification of target DNA. Amplification of DNA by both universal and E. necator-specific primers required the addition of PVP to the extraction buffer prior to homogenization and a phenol-chloroform extraction step. Potential PCR inhibitors (including incidental plant phenolics) were assumed to be sufficiently inactivated or removed by these modifications $(6,23,36)$. However, there appeared to be some loss of DNA since detection limits are not the same as when spores were placed directly in the PCR tube.

The level of sensitivity of this test makes it suitable for use in detecting airborne propagules of E. necator early in the progress of an epidemic when the information could be used to signal the commencement of the fungicide management program. With further development, the described approach may be useful in commercial settings to detect airborne inoculum prior to disease onset. Such an approach could have numerous potential benefits by using actual, rather than predicted, pathogen presence to make decisions about disease management. In vineyards containing overwintered chasmothecia, the approach could be used to make decisions to delay or eliminate fungicide applications, especially during dry years when precipitation is insufficient for ascospore release and primary infection. The technique also has potential usefulness in vineyards where no overwintered inoculum is present. Fungicide applications could be withheld until the pathogen is detected in air samples. For control programs based on intensive use of sulfur and/or oil, a reduction in the number of fungicide applications would be less disruptive to populations of beneficial insects (15) thereby contributing to the development of a more sustainable integrated pest management system. Fewer fungicide applications also would provide environmental benefits and would aid resistance management through reduced deployment of fungicides. The information gained from such monitoring could also facilitate the incorporation of an inoculum component into current $(11,17)$ and future powdery mildew forecasting and risk assessment models. When used in conjunction with on-site weather monitoring equipment and modeling techniques, the Rotorod sampling/PCR detection method should be a powerful tool in powdery mildew management regimes.

The continued development of this technology for implementation in commercial vineyards will depend on the density of spore traps required to accurately monitor for inoculum presence. We conservatively estimate that costs for using this technology will be $\$ 840$ per trap (24 samples collected costing \$35 [ \$10.00 in reagents, $\$ 5.00$ in labor ( $3 \mathrm{~h}$ at $\$ 20 / \mathrm{h}$ for 12 samples), $\$ 10$ for collection, $\$ 2.00$ capital costs, and $\$ 7.00$ profit] to process and report) for monitoring from bud burst to exhaustion of ascospore supply. This cost can be recouped by saving only one synthetic fungicide application ( $\$ 108 / \mathrm{ha})$ for compound and capital costs) on 7.8 ha or one application of sulfur (\$37/ha) on 22.7 ha. Our preliminary results indicate that vineyards of 22 ha can be monitored with only one trap, which indicates that this technology may be economically feasible today. As portable and inexpensive PCR and extraction equipment becomes available and applicable by untrained personnel, implementation of this approach would be even more likely.

\section{ACKNOWLEDGMENTS}

Washington State University Department of Plant Pathology New Series 0382 . A portion of this study was submitted as an M.S. thesis to the Washington State University by the first author. We acknowledge the financial support of this project by the Washington Wine Advisory Board, The American Vineyard Foundation, The Viticulture Consortium-West, The Northwest Center for Small Fruit Research, and the Washington State University Agricultural Research Center Project 0495, and USDA-ARS CRIS 5358-22000-030-00D. We thank D. Gadoury for insightful review of the manuscript. The use of trade, firm, or corporation names in this publication is for the information and convenience of the reader. Such use does not constitute an official endorsement or approval by the United States Department of Agriculture or the Agricultural Research Service of any product or service to the exclusion of others that may be suitable.

\section{LITERATURE CITED}

1. Altschul, S. F., Madden, T. L., Schaffer, A. A., Zhang, J. H., Zhang, Z., Miller, W., and Lipman, D. J. 1997. Gapped BLAST and PSI-BLAST: A new generation of protein database search programs. Nucleic Acids Res. 25:3389-3402

2. Braun, E. 1987. A monograph of the Erysiphales (powdery mildews). Nova Hedwigia 89:1-700.

3. Braun E. 1995. The Powdery Mildews (Erysiphales) of Europe. G. Fischer Verlag, New York.

4. Braun, E., Cook, R. T. A., Inman, A. J., and Shin, H. D. 2002. The taxonomy of the powdery mildew fungi. Pages 13-55 in: The Powdery Mildews: A Comprehensive Treatise. R. Belanger, W. Bushnell, A. Dik, and T. Carver, eds. American Phytopathological Society, St. Paul, MN.

5. Braun, E., and Takamatsu, S. 2000. Phylogeny of Erysiphe, Microsphaera, Uncinula, (Erysiphea) and Cystotheca, Podosphaera (Cystotheceae) inferred from rDNA ITS sequences - some taxonomic consequences. Schlechtendalia 4:1-33.

6. De Boer, S. H., Ward, L. J., Li, X., and Chittaranjan, S. 1995. Attenuation of PCR inhibition in the presence of plant compounds by addition of LOTTO. Nucleic Acids Res. 23:2567-2568.

7. Delye, C., and Laigret, F. 1997. A mutation in the $14 \alpha$-demethylase gene of Uncinula necator that correlates with resistance to a sterol biosynthesis inhibitor. Appl. Environ. Microbiol. 63:2966-2970.

8. Delye, C., Laigret, F., and Corio-Costet, M. F. 1999. Nested allelespecific primers distinguish genetic groups of Uncinula necator. Appl. Environ. Microbiol. 65:3950-3954.

9. Eichorn, K. W., and Lorenz, D. H. 1977. Phanologische Entwicklungsstadien der Rebe. Nachrichtenbl. Dtsch. Pflanzenschutzdienstes (Braunschweig) 29:119-120.

10. Grove, G. G. 2004. Perennation of Uncinula necator in vineyards of Eastern Washington. Plant Dis. 88:242-247.

11. Gubler, W. D., Thomas, C. S., Weber, E., Luvisi, D., Leavitt, G., and Smith, R. 1997. Use of a weather station based disease risk assessment for control of grapevine powdery mildew in California. (Abstr.) Phytopathology 87(suppl.):S36.

12. Guzman, P., Gepts, P., Temple, S., and Gilbertson, R. L. 1999. Detection and differentiation of Phaeoisariopsis griseola isolates with polymerase chain reaction and group-specific primers. Plant Dis. 83:37-42.

13. Hammett, K. R. W., and Manners, J. G. 1974. Conidium liberation in Erysiphe graminis. III. Wind tunnel studies. Trans. Br. Mycol. Soc. 2:267282.

14. Hirata, T., and Takamatsu, S. 1996. Nucleotide sequence diversity of rDNA internal transcribed spacers extracted from conidia and cleistothecia of several powdery mildew fungi. Mycoscience 37:238-288.

15. James, D. G., Price, T. S., Wright, L. C., and Perez, J. 2002. Abundance and phenology of mites, leafhoppers, and thrips on pesticide-treated and untreated wine grapes in Southcentral Washington. J. Agric. Urban. Entomol. 19:45-54.

16. Jimenez, L., Smalls, S., and Ignar, R. 2000. Use of PCR analysis for detecting low levels of bacteria and mold contamination in pharmaceutical samples. J. Microbiol. Methods 41:259-265.

17. Kast, W. K. 1997. A step by step risk analysis (SRA) used for planning sprays against powdery mildew (OiDiag-System). Vitic. Enol. Sci. 52:230-231.

18. Kong, P., Hong, C., Jeffers, S. N., and Richardson, P. A. 2003. A speciesspecific polymerase chain reaction assay for rapid detection of Phytophthora nicotianae in irrigation water. Phytopathology 93:822-831.

19. Lévesque, C. A. 2001. Molecular methods for detection of plant pathogens-What is the future? Can. J. Plant Pathol. 24:333-336.

20. Neter, J., and Wasserman, W. 1974. Applied Linear Statistical Models. 1st ed. Richard D. Irwin, Inc., Homewood, IL.

21. Pearson, R. C., and Gadoury, D. M. 1987. Cleistothecia, the source of primary inoculum for grape powdery mildew in New York. Phytopathology 77:1509-1514.

22. Peetz, A., Mahaffee, W., Grove, G., and Galloway, H. 2005. Rapid detection and quantification of airborne hop powdery mildew inoculum. (Abstr.) Phytopathology 95(suppl.):S81.

23. Porebski, S., Bailey, L. G., and Baum, B. R. 1997. Modification of a CTAB DNA extraction protocol for plants containing high polysaccharide and polyphenol components. Plant Mol. Biol. Rep. 15:8-15.

24. Rampersad, S. N., and Umaharan, P. 2003. Detection of begomoviruses in clarified plant extracts: A comparison of standard, direct-binding, and immunocapture polymerase chain reaction techniques. Phytopathology 93:1153-1157 
25. Saenz, G. S., and Taylor, J. W. 1999. Phylogeny of the Erysiphales (powdery mildews) inferred from internal transcribed spacer ribosomal DNA sequences. Can. J. Bot. 77:150-168.

26. Sambrook, J., and Russell, D. W. 2001. Molecular Cloning: A Laboratory Manual, 3rd ed., Cold Spring Harbor Laboratory, Cold Spring Harbor, NY.

27. Sholberg, P., O'Gorman, D., Bedford, K., and Lévesque, C. A. 2005. Development of a DNA macroarray for detection and monitoring of economically important apple diseases. Plant Dis. 89:1143-1150.

28. Stark, K. D. C., Nicolet, J., and Frey, J. 1998. Detection of Mycoplasma hyopneumoniae by air sampling with a nested PCR assay. Appl. Environ. Microbiol. 64:543-548.

29. Stummer, B. E., Zanker, T., and Scott, E. S. 1999. Cryopreservation of airdried conidia of Uncinula necator. Aust. Plant Pathol. 28:82-84.

30. Takamatsu, S., Hirata, T., and Yukio, S. 1998. Phylogenic analysis and predicted secondary structures of the rDNA internal transcribed spacers of the powdery mildew fungi (Erysiphaceae). Mycoscience 39:441-453.

31. Thompson, J. D., Higgins, D. G., and Gibson, T. J. 1994. CLUSTAL W: Improving the sensitivity of progressive multiple sequence alignment through sequence weighting, position-specific gap penalties and weight matrix choice. Nucleic Acids Res. 22:4673-4680.

32. Venkateswaran, K., Dohmoto, N., and Harayama, S. 1998. Cloning and nucleotide sequence of the gryB gene of Vibrio parahaemolyticus and its application in detection of this pathogen in shrimp. Appl. Environ. Microbiol. 64:681-687.

33. White, T. J., Bruns, T., Lee, S., and Taylor, J. 1990. Amplification and direct sequencing of the fungal ribosomal RNA genes for phylogenetics. Pages 315-322 in: PCR Protocols, A Guide to Methods and Applications. M. A. Innis, D. H. Gelfand, J. J. Sninsky, and J. W. White, eds. Academic Press, New York.

34. Williams, R. H., Ward, E., and McCartney, H. A. 2001. Methods for integrated air sampling and DNA analysis for detection of airborne fungal spores. Appl. Environ. Microbiol. 67:2453-2459.

35. Willocquet, L., Berud, F., and Clerjeau, M. 1998. Effects of wind, relative humidity, leaf movement, and colony age on dispersal of conidia of Uncinula necator, casual agent of grape powdery mildew. Plant Pathol. 47:234-242.

36. Zhou, G., Whong, W. Z., Ong, T., and Chen, B. 2000. Development of a fungus-specific PCR assay for detecting low-level fungi in an indoor environment. Mol. Cell. Probe 14:339-348. 